九州大学学術情報リポジトリ

Kyushu University Institutional Repository

\title{
TENEBRIONIDAE OF THE NANSEI ISLANDS IX (COLEOPTERA)
}

Chujo, Michitaka

https://doi.org/10.5109/2452

出版情報 : ESAKIA. 22，pp.1-4，1984-11-20. Entomological Laboratory，Faculty of Agriculture， Kyushu University

バージョン :

権利関係 : 
ESAKIA, (22) : 1-4. 1984

\title{
TENEBRIONIDAE OF THE NANSEI ISLANDS IX (COLEOPTERA)*
}

\author{
MichitaKa ChÛjô \\ Hikosan Biological Laboratory, Faculty of Agriculture, \\ Kyushu University, Hikosan, Fukuoka 824-07, Japan
}

\begin{abstract}
A new species, Catapiestus rugipennis from Amami-Oshima Island and Okinawa-Honto

Island, is described.
\end{abstract}

\section{Catapies tus rugipennis sp. nov.}

Catapiestus subrufescens : M. T. Châjô, 1977, Esakia, (10) : 10 (Amami-Oshima Island) (nec Catapiestus subrufescens Pic, 1911).

Catapiestus subrufescens: M. T. Châjô, 1978, Esakia, (11) : 70 (Okinawa-Honto Island).

Catapiestus subrufescens: M. T. Chûjô, 1982, Spec. Issue Mem. Retir. Emer. Prof. M. Chûjô : 94 \& 99

(Amami-Oshima Island \& Okinawa-Honto Island).

Elongate, parallel-sided, strongly depressed. Uniformly shining dark brown.

Head broad, flat, densely, strongly punctate, space between interocular area and occiput sparsely punctate ; clypeus weakly convex, marginal area narrowly reflexed, gradually narrowed forwards, front corner rounded, front margin widely, very shallowly sinuate ; front suture very fine, visible, semicircular ; gena convex, not expanded, roundly, very weakly narrowing apically; interocular area very wide, 4.5 times as wide as eye ; inner ocular margin narrowly ridged ; tempola weakly widened backwards and then acutely narrowing backwards ; neck slender, nearly cylindrical. Upside of eye relatively small, rounded, underside transverse, relatively large.

Antenna hardly reaching prosternal hind margin, 1st to 5th segments obconical, 6th to 10th subobtriangular, apical one oblong oval, apical 6 segments loosely clavate ; relative length of each segment (base to apex) $5: 3: 6: 4: 4: 4: 4: 4: 4: 4: 5$. Labrum transverse, semicircular, densely punctate, front margin with dense yellow hairs. Maxillary palpus with apical segment strongly securiformed. Mentum trapezoidally convex in the middle, roughly, sparsely punctate. Tempola to gula with rough punctures and transversal deep sutures.

Pronotum transverse $(2.8-3.0: 5.0)$, median $1 / 3$ sparsely punctate, lateral $1 / 3$ densely punctate, median line shallowly, very narrowly grooved, not reaching both

* Contribution from the Hikosan Biological Laboratory, Faculty of Agriculture, Kyushu University, Hikosan (Ser. 3, No. 3). 
margins ; front margin widely and shallowly sinuate, and reflexed laterally ; front corner obliquely, triangularly projected, apex obtuse ; side margin slightly reflexed, roundly warped outwards, strongly serrate ; hind corner obtusely angulate, about $80^{\circ}$; hind margin very shallowly bisinuate, narrowly, strongly marginate.

Prosternum gently convex, with irregular, sparse wrinkles and punctures ; propleuron very strongly, densely punctate ; prosternal process very wide, gradually dilated posteriorly, slightly projected from hind margin, apex truncate, widely, shallowly depressed between coxal cavities, depressed part irregularly, strongly punctate. Scutellum triangular, side margin slightly rounded, with large, shallow and very sparse punctures.

Elytra nearly parallel-sided, rounded at apex, with deep punctate-striae, very fine transversal wrinkles derived from every puncture ; interstices weakly convex, 7th interstices ridged ; basal margin obliquely truncate and finely marginate at basal $3 / 4$, relatively widely marginate at apical $1 / 4$. Epipleuron relatively wide at basal $4 / 5$, narrowed at apical $1 / 5$, reaching apex of elytron, densely, irregularly and strongly carved.

Mesosternum strongly, sparsely punctate, V-shaped receptor of prosternal process very wide, weakly convex, notched part widely, very shallowly depressed, depressed part roughly, sparsely punctate ; mesepisternum densely, strongly punctate ; mesepimeron sparsely, shallowly carved. Metasternum weakly convex, median part widely, shallowly depressed, especially roughly, strongly depressed at postero-interior part of middle coxal cavity, depressed part sparsely, very strongly punctate.

Every femur elongate spindle-shaped, weakly compressed, with dense, large and deep punctures ; front one with shallow femoral groove, both sides of groove distinctly ridged, with dental projection at middle part on upper ridge sometimes vestigial, subapical part of upper ridge distinctly constricted ; middle and hind ones with frontal groove at hind margin, both sides of groove distinctly ridged as in front one, lower ridge acutely truncate at $4 / 5$ from base.

Front tibia comparatively thick, stout, square-bar-shaped, outwardly, roundly curved, gradually dilated towards apex, interior and lower faces shallowly grooved longitudinally in the middle, median part of outer face roundly ridged longitudinally, apex with pale brown short hairs which are arranged in a row, tibial spur very thin, short ; middle tibia very similar to front one; hind tibia relatively slender, very feebly dilated apically, feebly, roundly curved outwards. Front tarsi thick, short, sole with sparse, pale brown long hairs, relative length of each segment (base to apex) $4: 3: 4$ : $4: 22$, apical one abruptly dilated towards apex, claw very thick; hind tarsi comparatively slender, long, relative length of each segment (base to apex) $8: 5: 5: 23$.

Visible abdominal sternites evenly, sparsely, strongly punctate and shallowly, irregularly wrinkled; 1 st to 3rd sternites with wide and shallow depressions near side margin, suture between 3rd and 4th sternites, and that between 4th and 5th widely, deeply grooved, 5th semicircular.

Length :11.6-15.4 mm. Width : 4.1-9.5 mm.

Distribution : Ryukyus (Amami-Oshima Island \& Okinawa-Honto Island). 


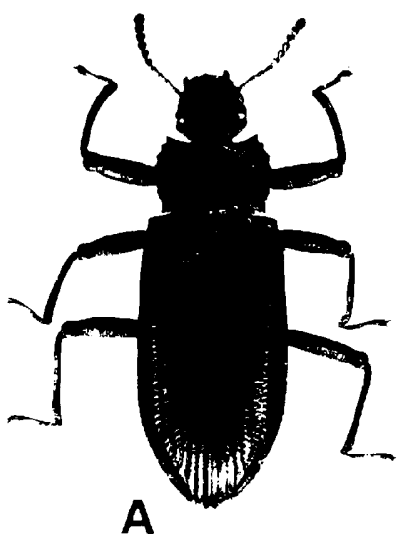

A
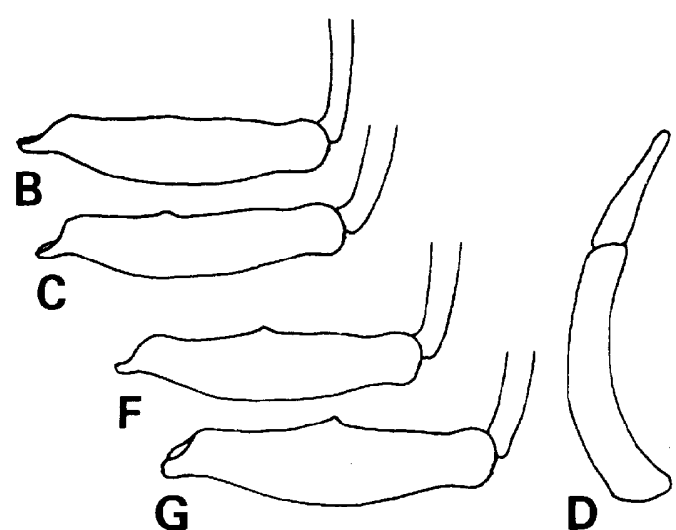

E

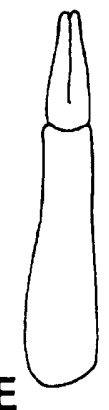

A : Catapiestus mgipennis sp. nov. B : Ditto, vestigial pattern of front femoral dental projection in dorsal view. C: Ditto, well-developed one. D : Lateral view of male genitalia. E: Ditto, dorsal view of male genitalia. F : Catapiestus subrufescens Pic, less-developed pattern of front femoral dental projection in dorsal view. G: Ditto, well-developed one.

Type matErial: Holotype ơ (Type No. 2453, Kyushu Univ.), Mt. Yonaha-dake, Okinawa-Honto Is., 1. vi. 1974, H. Irie leg.

Paratypes : AMAMI-OSHIMA IS. : $q$ (U. S. -Japan Co-op. Sci. Programme), Mt.

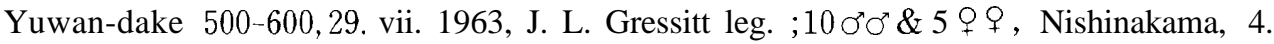
vii. 1976, H. Makihara leg. ; $20^{\top} \sigma^{\top} \& \&$, Marubata-rindo, 8. vii. 1976, T. Tsutsumi leg. OKINAWA-HONTO IS. : $q$, Mt. Yonaha, 26. iii. 1973, H. Irie leg. ;2$q q$, Mt. Yonaha, 28. iii. 1973, H. Irie leg. ; $\uparrow$, Mt. Yonaha, 22. iv. 1973, H. Irie leg. ; $\sigma^{\prime} \&$, Mt. Yonaha, 17. iv. 1974, H. Irie leg. ; $\sigma^{\prime}$, Oku, 31. v. 1974, H. Irie leg. ; $q$, Mt. Yonaha, 2. iv. 1975, H. Irie leg.; O'\& $\&$, Aha, 4. iv. 1975, H. Irie leg. ;2qq, Hiji, 6. iv. 1975, H. Irie leg. ; $q$, Y ona, 3. v. 1975, T. Tsutsumi leg. ; $11 \sigma^{\circ} \sigma^{\prime} \& 3 q q$, Yona, 30. vi. 1976, H. Makihara leg. ; 8 ơ $^{\prime} \& 8$ qq (at light), Yona, 29. vi. 1976, H. Makihara leg. ; 18 ơ \& 7 우, Oku, 30. vi. 1976, H. Makihara leg. ; $110^{\prime} \sigma^{\top} \& 3 q q$, Yona, 30. vi. 1976, H. Makihara leg. ; $\checkmark \&$ \& Y Yona, 4. vii. 1976, T. Tsutsumi leg. Paratopotypes :36 ठర \& $13 \uparrow q$, same data as holotype.

This new species is closely related to C. subrufescens Pic, 1911 from Formosa, and once I considered these as the same species. However, the new species is distinguished from the latter by the following characters : smaller in size (ca. $82 \%$ ), elytral strial punctures smaller and fewer, every puncture associated with fine lateral wrinkles, mentum with sparse and fine punctures, and front femoral dental projection much smaller or sometimes vestigial.

Note: External sexual difference is not recognized.

JAPANESE NAME : Hime-hirata-gomimushidamashi.

\section{Acknowledgements}

I wish to express my appreciation to Prof. Y. Hirashima, the head of Hikosan Biological Laboratory, for making this study possible and for his kind guidance in the 
preparation of the manuscript. Also, I express my cordial thanks to Prof. Emeritus M. Chûjô of Kagawa University and Mr. T. Shibata of Osaka City for their continual kind and valuable advice. I thank Mr. H. Makihara of Forestry and Forest Products Research Institute and Mr. H. Irie of Fukuoka City for their kind gifts of the valuable Ryukyuan tenebrionid specimens. 